\title{
Business process management and risk-adjusted performance in SMEs
}

\author{
Dušan Gošnik and Igor Stubelj \\ Faculty of Management, University of Primorska, Koper, Slovenia
}

\begin{abstract}
Purpose - This paper aims to examine the relationship between business process management (BPM) and company performance. The research focuses on the instrumental aspect of core business processes and its controlling activities in small and medium-sized companies (SMEs) to identify the relationship to company performance.
\end{abstract}

Design/methodology/approach - The results presented in this paper are based on a survey of Slovene SMEs. A questionnaire was distributed to 3007 SMEs via e-mail and a response rate of $5.42 \%$ was achieved. The financial data of companies over a six year period as derived from the publicly available financial reports of SMEs along with an industry-specific financial risk measure and other financial data were used for the company riskadjusted performance measures of relative residual income (ROE- $r$ ) and risk-adjusted ROE (ROE-a) calculation.

Findings - The results show that instrumental aspects of core business process controlling activities are related to risk-adjusted company performance measures ROE- $r$ and ROE-a. Companies with lower ROE- $r$ and ROE-a have been perceived to be more focused on the instrumental aspect of BPM. Presumably due to the small sample, the results of a non-parametric Mann-Whitney $U$ test did not statistically confirm the developed hypothesis: "the instrumental aspect of controlling as a core process management activity has a statistically significant impact on company risk-adjusted performance measures such as ROE- $r$ and ROE-a." Despite this, the results show a possible negative correlation between risk-adjusted performance measures and BPM, which opens possibilities for further research.

Research limitations/implications - The main limitation of the purposed study model is that the paper have studied only control activities of core business processes and relate it to company risk-adjusted performance measures. The study has been limited by the SME sample and the use of a survey as a research instrument. An additional limitation of the research is the degree of reliability implied by the assumptions of the models used to estimate the required return on equity and risk. Results concern investors, managers and practitioners to start BPM improvement initiatives, to set BPM priority measures and to set priority management decisions and further actions.

Originality/value - This paper presents the unique findings from an investigation of the instrumental aspects of BPM practices and their relationship to company risk-adjusted performance measures in SMEs. This paper developed a measurement instrument for measuring the instrumental aspects of BPM use. An additional original contribution is the use of company risk-adjusted performance measures such as ROE- $r$ and ROE-a, which take into account the required profitability of companies in different industries according to the risk and allows comparable results of companies from different industries. The approach is innovative and interesting as regards researching the factors that affect the profitability of companies that operate in different industries.

Keywords Risk management, Management, Measurement, Business systems, BPM, Core processes, Company, Performance, Risk-adjusted performance measures, SMEs, Slovenia

Paper type Research paper

(C) Dušan Gošnik and Igor Stubelj Published by Emerald Publishing Limited. This article is published under the Creative Commons Attribution (CC BY 4.0) licence. Anyone may reproduce, distribute, translate and create derivative works of this article (for both commercial and non-commercial purposes), subject to full attribution to the original publication and authors. The full terms of this licence may be seen at http://creativecommons.org/licences/by/4.0/legalcode
Business

process

management

\section{Received 18 November 2020 \\ Revised 13 January 2021}

Accepted 19 February 2021

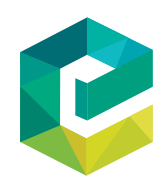

Kybernetes

Vol. 51 No. 2, 2022 pp. $659-675$ pp. 659-67
Emerald Publishing Limited
0368-492X DOI 10.1108/K-11-2020-0794 
$\mathrm{K}$

51,2

\section{Introduction}

The competitiveness of every company arises from the competitiveness of its business processes. Business processes determine the quality, innovation and productivity (efficiency) of companies (Potočan and Mulej, 2009; Minonne and Turner, 2012). Business processes in any organization determine operating costs and affect business performance (Seethamraju, 2012). We can define the business process as a comprehensive and dynamic coordinated set of connected activities, from purchasing to sales, which are intended for the appropriate supply of customers and enable a successful business performance of a company in a particular economic environment (Janeš et al., 2017; Janeš et al., 2018; Novak and Janeš, 2019). It follows that, in accordance with the need for process orientation, each company should plan, organize, lead and control its business processes. It is described as business process management (BPM). Among all the business processes of a company, the core business processes contribute to company performance the most (Thennakoon et al., 2018; Zelt et al., 2018). If the core processes are innovative, this will be reflected in the performance of the company (Thennakoon et al, 2018; Gošnik, 2019a, 2019b). From this perspective, the management of core processes in companies should be the priority focus of managers and company owners. Previous research studies on this field show us some relations between core business processes and company performance and that a lack of measurement at BPM implementation results in less successful implementation of BPM (Gošnik et al., 2016; Stojanović et al., 2017; Gošnik, 2019a, 2019b). Company performance in these researches was not related specifically to risk-adjusted company performance measures ROE- $r$ and ROE-a, which has been detected as a research gap and is attracted our focus in this research.

BPM is a complex area which includes the management activities of planning, organizing, leading and controlling of business processes and is influenced by a number of factors, which cannot all be included in this research. We will take into consideration control activities of core business processes and relate it to company risk-adjusted performance measures. The goal of this research is to examine how controlling activities of core business process are related to risk-adjusted company performance measures ROE- $r$ and ROE-a We have tested hypothesis: "the instrumental aspect of control as a core process management activity has a statistically significant impact on the company risk-adjusted performance measures ROE- $r$ and ROE-a." Methodology used for data analysis was Bartlett's test, Kaiser-Maier-Olkin test (KMO) and Mann-Whitney U test.

This research presents the unique findings from an investigation of the instrumental aspects of BPM practices and their relationship to company risk-adjusted performance measures in SMEs. We developed a measurement instrument for measuring the instrumental aspects of BPM use.

Paper is organized as follows: literature overview, BPM and instrumental aspect of organization, the overview of company performance and company risk-adjusted company performance measures and hypothesis development. An empirical study with results and discussion is presented with the limitations and further research possibilities described.

\section{Literature review}

\subsection{Business process management and core business processes}

Niehaves et al. (2014) define BPM as a synthesis of different managerial practices and approaches for business optimization that enable differentiation and the competitiveness of companies. BPM requires the development and implementation of innovative solutions in businesses and enables the differentiation and competitiveness of companies. Thennakoon et al. (2018), Espino-Rodriguez and Rodríguez-Diaz (2014) highlight the importance of the 
connection of business processes with the objectives of a company, targeting the benefit to the customer and other participants, as well as emphasizing that we must have clearly set criteria for measuring the effects of processes on company performance. Business processes of a company can be classified into operating (core) processes (vision and strategy development, products and services development, selling, delivery, customer service) and management/support processes (development of human capital, managing IT, managing finances, assets, risks, relationships and managing business capabilities) (APQC, 1992). Among all the business processes of a company, the core business processes contribute to company performance the most (Thennakoon et al., 2018; Zelt et al., 2018). Core process management involves both:

- interests of customers, suppliers, employees; and

- instrumental aspects (interest of company owners and managers) (Tavčar, 2009; Burlton, 2010; Vom Brocke et al., 2014; Trkman et al., 2015).

\subsection{Instrumental aspect of an organization}

Every organization is an instrument (a machine, device) for achieving objectives and is subordinate to the interests of the owners and founders (Stalk et al., 1992; Inkpen and Choudhury, 1995; De Wit and Meyers, 2005; Tavčar, 2009). This is also reflected in the management of a company and the core activities of management (planning, organizing, leading and controlling). Employees and processes are monitored continuously, with an emphasis on costs, productivity and maximizing short-term profit rather than the long-term growth and development of the organization (Tavčar, 2009). It is reflected in the quantitative measurement of processes and company performance. According to Trkman (2010), unsuccessful implementation of changes in the business processes are connected to the fact that management does not take into account instrumental aspects. Therefore, our research in the empirical part focuses especially on the instrumental aspects of controlling core business processes and the effect of this on company performance.

\subsection{Business processes and company performance}

Nandakumar et al. (2009) define a company's performance as the degree to which objectives are achieved (profit) and success in relation to the competition. Berends et al. (2016) interpret a company's performance in terms of reputation and capacity to adjust to the changes of the environment and suggest that performance measuring would include several measures: financial, operational and comprehensive. Various authors (De Wall, 2008; Strecker, 2009) suggest the inclusion of periods from one to three years and consideration of the average values of individual measures to achieve a more objective assessment.

When we compare the performance of companies between different industries the use of profitability ratios across industries without risk adjustment is not appropriate. Investing in companies is risky. Investors can avoid part of the risk by diversifying their investments, but they cannot completely avoid risk. According to the well-known and widely used risk and return model in practice, which is the capital asset pricing model or CAPM (which is used and presented later in the paper) the average investor is risk-averse which means that he must be compensated for bearing risk. He seeks investments that have the best-expected risk/return ratio. This creates a link between risk and return. To obtain the required capital, companies must prove that they can achieve the appropriate profitability for the level of risk. Only if a company's return on capital is higher than the required return that accounts for risk, will the investment add value for owners. In view of the above, the only way to

Business process management

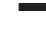


$\mathrm{K}$

51,2

correctly examine the relationship between BPM and company performance across different industries is to use risk-adjusted performance measures.

\subsection{Company risk-adjusted performance measures}

To measure the efficiency of invested capital, a company's profitability ratios such as profit margin, basic earning power, return on assets and return of equity are used in practice. In addition, to evaluate the management performance of non-listed companies (for which the equity market value is unknown) in achieving the purpose of capital companies, which is to increase the value for owners, the criterion usually used is profitability ratios. This is suitable if we compare companies from the same or similar industries that have a similar level of risk.

Based on the irrefutable fact that profitability and risk are correlated, the required return of a business depends on the level of risk involved. In accordance with this fact, we will test management approaches with two risk-adjusted profitability measures based on return on equity (ROE).

2.4.1 Residual income approach as a risk-adjusted equity capital performance measure. Finance theory says that the primary goal of managers is to increase value for the equity owners of companies [1]. In practice, this means increasing the value of assets, which leads to growth in the value of equity. However, to measure management performance, we need criteria that tell us whether management increases the value of equity. Managers also need such measures to make decisions. These criteria should take into account the fact that valueadded for owners is created only when the expected return is higher than the required one, which takes into account the risk. Glen (2005) argued that managers will not be able to define the consequences of their decisions without being aware of this. The concept of residual income as a performance measure and valuation tool could be used. This was introduced in the early 1920s and infrequently used since, despite its interesting underpinning. Stewart's publication in 1991, in which the authors presented their "modernized" version of residual income referred to as economic value added or EVA $₫$, has renewed interest in the concept (Christensen et al., 2002). An interesting contribution of this model is the aspect that a company's positive net income does not necessarily imply that a company is creating value for its owners.

We start from the residual income valuation model (RIV) that is an appealing approach and which received attention in the accounting literature for its apparent ability to give a constructive role to accounting data in equity valuation. Many researchers have explored the pros and cons of the RIV model as a useful valuation tool [2] as proved by many publications. We will use the concept of residual income as a relative measure of riskadjusted return.

We can currently estimate residual income with the following equation (Halsey, 2001):

$$
R I_{0}=E_{0}-r \cdot B V_{-1}
$$

where $R I_{0}$ is the present value of residual income, $E_{0}$ is the present value of net income, $r$ is the required return of equity capital, $B V_{-1}$ is the book value of equity capital in the previous period. The value of expected residual incomes can be expressed as:

$$
\frac{R I_{1}}{r}=\frac{E_{1}-r \cdot B V_{0}}{r}
$$

The value of equity capital with constant growing expected residual income can be calculated as: 


$$
V_{0}=B V_{0}+\frac{R I_{1}}{r-g_{R I}}=B V_{0}+\frac{E_{1}-r \cdot B V_{0}}{r-g_{R I}}
$$

\section{Business} process

where $R I_{1}$ is the expected residual income, $E_{1}$ is the expected net income, $B V_{0}$ is the book value of equity capital and $g_{R I}$ is the expected growth rate of residual income. A company adds value for its owners if residual income is positive. For the purposes of our analysis, we have expressed the relative residual income with the following equation:

$$
R I_{t}(\%)=\frac{R I_{t}}{\frac{B V_{t-1}+B V_{t}}{2}}=\frac{E_{t}-r_{t} \cdot \frac{B V_{t-1}+B V_{t}}{2}}{\frac{B V_{t-1}+B V_{t}}{2}}=\frac{E_{t}}{\frac{B V_{t-1}+B V_{t}}{2}}-r_{t}
$$

by a simplification based on the ROE calculation equation we have:

$$
R I_{t}(\%)=R O E_{t}-r_{t}
$$

where $R O E_{t}$ is return on equity capital for year $t, R I_{t}$ is the residual income for the year $t$, $B V_{t-1}$ is the book value of equity capital at the end of the year $t-1, E_{t}$ is the net income for year $t, \mathrm{BV}_{\mathrm{t}}$ is the book value of equity capital at the end of the year $t$ and $r_{t}$ is the required return of equity capital estimated in the year t. $R I_{t}(\%)$ is the residual income in per cent or relative residual income which we will denote as residual ROE or ROE- $r$.

To calculate the relative residual income we need to estimate the required return on equity capital which is the essential parameter for the residual income calculation. Required return on equity was estimated using the CAPM developed independently by Treynor (1961, 1962), Sharpe (1964), Lintner (1965a, 1965b), Mossin (1966). The CAPM equation is:

$$
r_{i}=r_{f}+\beta_{i} \cdot\left(r_{m}-r_{f}\right)
$$

Where $r_{i}$ is a required return of equity $\mathrm{i}, \gamma_{f}$ is the risk free rate, $\beta_{i}$ is the beta coefficient (measure of market risk) of equity $\mathrm{i}_{2} r_{m}$ is the market return on equity, and the $\left(r_{m}-r_{f}\right)$ is the market risk premium.

Despite some very strong and unrealistic assumptions [3], no doubt due to its "simplicity," CAPM is in practice the most widely used model for determining the required return on equity [4]. However, the discussion on the validity of the CAPM is still ongoing. Severe criticism and scepticism in relation to the validity of CAPM have been expressed by McGoun (1993), Fernandez (2015). In addition, Fama and French (1992) demonstrated that the CAPM does not explain a substantial fraction of market returns.

2.4.2 Systematic risk-adjusted return on equity approach as a risk-adjusted equity capital performance measure. It is necessary to adjust ROE with the systematic risk measure for a specified industry. The following assumptions must be made:

- $\mathrm{ROE}$ and market returns are equal in the long-term; and

- investors can avoid the specific risk of ROE with diversification and only the systematic risk matters.

We search for the return which can be compared to the market return at a given level of risk. We substitute the required return with ROE and the market return with the adjusted ROE (in the CAPM equation). We rearrange the equation to calculate the company's risk-adjusted ROE: 


$$
R O E_{i, \text { Adjusted }}=\frac{R O E_{i}}{\beta_{i}}+r_{f} \cdot\left(1-\frac{1}{\beta_{i}}\right)
$$

where $R O E_{i, \text { Adjusted }}$ is a ROE of company $\mathrm{i}$, adjusted for the market risk which we will denote as ROE-a, $R O E_{i}$ is a ROE of company $i, \beta_{i}$ is the measure of the market (systematic) risk for a company and $r_{f}$ is the risk free rate of return.

Performance measures ROE- $r$ and ROE-a derived as explained above take into account differences in systematic risk between industries. Such measures are more appropriate than ROE to examine the relationship between BPM and company performance across different industries.

\section{Research methodology}

Based on the theoretical background, we relate core business processes to company performance. We focus on the instrumental aspect of controlling the activities of business processes and relate them to company performance, measured with the risk-adjusted performance measures ROE- $r$ and ROE-a.

Based on theoretical starting points in the theoretical part and detected research gap we have developed hypothesis H: "'the instrumental aspect of control as a core process management activity has a statistically significant impact on the company risk-adjusted performance measures ROE- $r$ and ROE-a."

Based on the literature overview we have developed measuring instruments (statements) for measurement of the instrumental aspects of controlling core business processes and their effect on company performance. As part of the hypothesis validation, we investigated:

- whether there are statistically significant connections between core process management activities and the performance of a company;

- whether the hypotheses is valid; and

- how is the instrumental aspect of controlling core processes related to the company risk-adjusted performance measures ROE- $r$ and ROE-a.

\subsection{Data collecting methodology}

We used an online questionnaire to collect the data. We developed it through a review of the literature in the theoretical part of the research.

The questionnaire was comprised of several thematic sections. The questionnaire was comprised of closed-ended questions. In terms of the nature of the questions, we included questions of fact. Respondents provided their degrees of agreement with the statements made. We used a six-point Likert scale to avoid responses falling into the middle of the scale (Easterby-Smith et al., 2007). Within the context of hypothesis, we developed a set of statements that measure the instrumental aspects of controlling core processes. The indicator of influence was the estimated degree of agreement by the respondents to each claim.

The performance of SMEs risk-adjusted measures ROE- $r$ and ROE-a was calculated comprehensively using secondary data from different sources. We calculated the riskadjusted performance for five years.

\subsection{Validation of the questionnaire}

In terms of content, the measuring instrument was developed through a review of the literature in the theoretical part of the research. The reliability of the questionnaire was 
verified using the Cronbach alpha $(\alpha)$ coefficient, which is intended to measure the internal consistency of the measuring instrument. The questionnaire was further pre-tested in an academic setting before being sent to the companies.

Business process management

\subsection{Financial data of companies used for company risk-adjusted performance measures}

In total, 163 companies responded to our questionnaire. In regard to all companies, the financial data was collected from the balance sheet and income statement of Slovenian companies for the period 2011-2016. For each company, we obtained data regarding net income, financial debt and equity from the Gvin available financial database. For some companies, data was not available for all the years in question (some companies did not operate throughout the entire period analyzed) and we excluded those companies. We also excluded from our further analysis all the companies with negative equity capital. Our final data set with financial data available included 149 companies.

\subsection{Data analysis}

Within the framework of statistical processing of the collected data in the empirical part, and to test the hypothesis, we used the following tests in the SPSS program (version 24.00):

- The relationship (correlation) between variables or assertions within a factor, which we call a factor in the statistical analysis phase, is analyzed and presented with the assistance of Bartlett's test and KMO test.

- Mann-Whitney U test.

\section{Findings}

4.1 Research population and sample

The target population in our survey were SMEs, which at the time of our survey on 11th of January 2017 were in the public database of business entities with headquarters in the Republic of Slovenia (Ajpes). Questionnaires were addressed to all 3,007 SMESs in Slovenia and their general managers. We have asked them to participate in the research or to include their co-workers who have the best insight into BPM practice in the company. That possibility was considered before research start and included in the questionnaire. Respondents in this research were business function managers $(35 \%)$, general managers $(27 \%)$, followed by business process owners $(7.4 \%)$, project managers $(4.3 \%)$, technical managers $(2.5 \%)$ and others $(23.9 \%)$. We assume that questionnaires were fulfilled by the most qualified employees in the SME's and that results reflect real status of BPM in the SMEs.

We received 163 company questionnaires. Of those, 44.8\% were small companies and $55.2 \%$ were medium-sized companies. Given the initial sample framework of 3,007 companies, this represents a $5.42 \%$ response rate. The majority of the companies included in this research operate in the manufacturing and processing (37.4\%), wholesale and retail trade activities (10.4\%) and construction (6.7\%) sectors. The remaining $45.5 \%$ of companies are distributed between other industries.

When we matched the questionnaires with financial data, we obtained a data set of 149 companies. We eliminated 14 companies that had incomplete financial data or negative equity capital during the period in question. 
$\mathrm{K}$

51,2

\section{6}

Table 1.

Instrumental aspects of core business processes - control

\subsection{Instrumental aspects of core business processes - control}

In Table 1, we present the results of the measurement system for measuring instrumental aspects of core business processes control. The main purpose is to ensure that our measurement system is appropriate, which is one of the original contributions of this research.

As we see in Table 1, companies are using the most common practice; that changes to the core processes are measured by financial effects (4.48 out of 6 ). In addition, the statement about clearly defined indicators to measure core process changes was rated quite highly (4.02 out of 6). Based on the statements from Table 1, we have analyzed the relationship between statements (Table 2). An analysis of the relationships between statements (Tables 2 and 3) is important to ensure that our statements for measuring the instrumental aspects of business process control activities are consistent and appropriate for further analysis. An analysis of

Tables 2 and 3 shows the results of the Bartlett test and KMO value.

The results show that the KMO value is 0.614 , Hi square $=118,766$. The Bartlett test is statistically significant in that it shows us a $p$-value which is under 0.05 . The results show that statements for measuring instrumental aspects of business process control activities are appropriate for further analysis.

Statements for measuring instrumental aspects of core business processes are wellcorrelated, demonstrating a correlation analysis with values higher than 0.3 (Phanny, 2009) (Table 3).

The determinant is 0.395 , which is more than 0.00001. According to Yong and Pearce (2013), our statements for measuring the instrumental aspects of core business processes control are consistent and appropriate for use in further research.

\section{Statement}

Avg. St. Skewness Kurtosis

The success of changes to the core processes is measured with the assistance of clearly defined indicators

(1-6) dev. Koef. Koef.

The success of changes to the core processes is measured by financial effects

We do not deviate from the set goals of changes to the core processes in our company

When measuring the success of changes to the core processes, we put short-term (immediate) benefits for the company in the foreground Total $\begin{array}{llll}4.02 & 1.254 & -0.073 & -0.780\end{array}$

$\begin{array}{llll}4.48 & 1.033 & -0.572 & 0.177\end{array}$

$\begin{array}{llll}3.63 & 1.122 & 0.103 & -0.212\end{array}$

$\begin{array}{llll}3.12 & 1.190 & 0.316 & -0.487\end{array}$

3.81

KMO test

Table 2.

Bartlett test

KMO and Bartlett 


\begin{tabular}{|c|c|c|c|c|c|}
\hline Statement & $\begin{array}{l}\text { The success of changes } \\
\text { to the core processes is } \\
\text { measured with the } \\
\text { assistance of clearly } \\
\text { defined indicators }\end{array}$ & $\begin{array}{l}\text { The success of } \\
\text { changes to the } \\
\text { core processes is } \\
\text { measured by } \\
\text { financial effects }\end{array}$ & $\begin{array}{l}\text { We do not deviate } \\
\text { from the set goals } \\
\text { of changes to the } \\
\text { core processes in } \\
\text { our company }\end{array}$ & $\begin{array}{l}\text { When measuring the } \\
\text { success of changes to } \\
\text { the core processes, we } \\
\text { put short-term } \\
\text { (immediate) benefits } \\
\text { for the company in the } \\
\text { foreground }\end{array}$ & $\begin{array}{r}\text { Business } \\
\text { process } \\
\text { management } \\
\mathbf{6 6 7}\end{array}$ \\
\hline $\begin{array}{l}\text { The success of changes } \\
\text { to the core processes is } \\
\text { measured with the } \\
\text { assistance of clearly } \\
\text { defined indicators } \\
\text { The success of changes } \\
\text { to the core processes is } \\
\text { measured by financial } \\
\text { effects } \\
\text { We do not deviate from } \\
\text { the set goals of } \\
\text { changes to the core } \\
\text { processes in our } \\
\text { company } \\
\text { When measuring the } \\
\text { success of changes to } \\
\text { the core processes, we } \\
\text { put short-term } \\
\text { (immediate) benefits } \\
\text { for the company in the } \\
\text { foreground }\end{array}$ & $\begin{array}{l}s \\
s \\
s \\
s \\
s\end{array}$ & 1,000 & 1,000 & 1,000 & $\begin{array}{r}\text { Table } 3 . \\
\text { Correlation between } \\
\text { statements: } \\
\text { Instrumental aspects } \\
\text { of core business } \\
\text { processes - control }\end{array}$ \\
\hline
\end{tabular}

\subsection{Estimation of input variables and company risk-adjusted performance measures}

4.31 Input variables estimation. For the calculation of company risk-adjusted performance measures, we estimated the risk-free rate of return and the market risk premium for the Slovenian financial market and the systematic risk measure for each company. Estimating this variables practice is not straightforward due to the lack of an ideal method, and is an especially challenging task on a capital market like that of Slovenia [5]. A practical solution is the use of data from a developed capital market with adjustment. In our empirical analysis, we used all data from the US market as we found coverage for all the analyzed years and then we adjusted this data for the Slovenian capital market. We did not mix data from different markets to prevent additional bias.

We estimated a long-term equilibrium risk-free rate of return for every observed year as the average yield to maturity of U.S. indexed bonds (30-Year 3\%-7/8\% Treasury InflationIndexed Bond, Due 4/15/2029) [6] of the last ten years (monthly data). According to the European Central Bank (2020) target inflation rate [7], we added the expected inflation of $2 \%$ to obtain the nominal risk-free rate of return.

We estimate a market risk premium with two approaches as follows and then we calculated the average: [8]

(1) We used the average of the implied market risk premium estimations from Damodaran (2020) in the past 10 years before each of our observed years. The fluctuations of the risk aversion between the observed years are incorporated in the implied market risk premium. We also assumed that investors have the option 
$\mathrm{K}$

51,2

\section{8}

Table 4.

Estimated

parameters to sweep away country-specific risk with global diversification, and consequently the capital market does not reward investors with additional country risk premium:

(2) We assumed a long-term sustainable market risk premium of 4\% [9] to which we added a country risk premium for each year. To obtain the country risk premium we used the relative volatility of stocks versus bonds market which we multiplied with the average of credit-rating estimated default swap, and a credit default swap for Slovenia net of United States credit default swap [10]. A country risk premium is not theoretically supported in the CAPM [11], however, it is widely used in practice. The rationale for our second approach is that a long-term market risk premium is stable over time, with short-term fluctuations in the investor's risk aversion. We account for these fluctuations through a country risk premium with the logic that the greater the aversion to risk on the capital market, the greater the country risk premium and consequently the market risk premium.

For the measure of risk, we used betas (i.e. market risk measures) of the US companies, which can be accessed at Damodaran (2020) [12]. In this analysis, we apply sector-level data for unlevered betas, calculated for all the observed years (2012 to 2016), by which we translated the industry sectors used by Damodaran (2020) to the Slovenian NACE Rev. 2 industry classification. For each industry in this classification, we calculated the average unlevered betas. In the next step, we used average unlevered industry betas to calculate the firm-level leveraged beta by applying the Hamada equation and adapting beta for relevant tax rates on profit and the company's debt-to-equity ratio. The Hamada equation is:

$$
\beta_{1}=\beta_{\mathrm{u}} \cdot\left[1+(1-\mathrm{T}) \cdot\left(\frac{\mathrm{W}_{\mathrm{d}}}{\mathrm{W}_{\mathrm{s}}}\right)\right]
$$

where $\beta_{l}$ is the leveraged beta for the company, $\beta_{u}$ is the unleveraged beta for the industry, $w_{d}$ and $w_{s}$ weights of equity capital and debt, where $w_{d}+w_{s}=1, T$ is the corporate tax rate. The end estimated parameters used for the CAPM are presented in Table 4. Calculations were made based on data from Damodaran (2020), Fred (2020), European Central Bank (2020), Bloomberg (2020) and Gvin (2020).

Table 4 shows the estimated parameters for the Slovenian market (in accordance with the explanation above) in the analyzed years that were entered in the CAPM model.

4.3.2 Adjusted performance measures estimation. We estimated all the parameters in accordance with the theoretical basis and methodology described in the previous chapters. In Tables 5 and 6, we present the average values in comparison with the aggregated Slovenian company data. In further analysis, individual companies are used.

As we see from the tables, the median leveraged beta in all the analyzed years is more than one. Assuming that the US companies from which the betas are calculated have an average debt and distribution of companies between industries similar to that of all

\begin{tabular}{lccccc}
\hline Variable/Year & 2012 & 2013 & 2014 & 2015 & 2016 \\
\hline Real risk-free rate (\%) & 1.90 & 1.69 & 1.55 & 1.42 & 1.24 \\
Nominal risk-free rate (\%) & 3.90 & 3.69 & 3.55 & 3.42 & 3.24 \\
Estimated market risk premium (\%) & 6.51 & 6.67 & 6.24 & 6.10 & 5.97 \\
\hline
\end{tabular}


Slovenian companies, we can deduce that in the median our analyzed companies are more risky than the median Slovenian company (Tables 5 and 6).

Despite this assumption, which is not likely to be true, the greater ROE of analyzed companies in comparison to the aggregated ROE of all Slovenian companies demonstrate the positive relationship between risk and return. The relative residual income (in \%) is negative in the entire analyzed period except in 2016 (Tables 5 and 6).

These results simply indicate that in the median in the period from 2012-2015, capital owners/investors in the analyzed companies were losing the value of their invested equity capital. (Figure 1) Calculations were made based on Damodaran (2020), Fred (2020), European Central Bank (2020), Bloomberg (2020), Gvin (2020).

But looking at the aggregate ROE of all Slovenian companies we can also assume that on average all Slovenian companies performed below the required return in the same period and consequently have had negative residual income in that period. However, the results have a positive trend in the analyzed period due to the increasing ROE and the decreasing required return on equity (mostly due to decreased risk) (Figure 1).

Based on financial data about company performance and results in the previous chapters we have researched the connection between the instrumental aspects of core business process control activities and ROE- $r$ and ROE-a. According to the aim of our research, to

\begin{tabular}{lrrrrr}
\hline Aggregated ROE in \% & 2012 & 2013 & 2014 & 2015 & 2016 \\
\hline Median ROE of all analyzed companies $(n=149)$ & 7.03 & 10.50 & 11.96 & 11.24 & 11.24 \\
Aggregate ROE of all Slovenian companies & 0.88 & 0.45 & 2.37 & 4.86 & 7.79 \\
Difference & 6.15 & 10.05 & 9.59 & 6.38 & 3.45 \\
\hline
\end{tabular}

\section{Business process management}

669

Table 5. Aggregated ROE of all Slovenian companies and median ROE of all analyzed companies

\begin{tabular}{lrrrrrr}
\hline Median $(n=149)$ & 2012 & 2013 & 2014 & 2015 & 2016 & \\
\hline Levered beta of all analyzed companies & 1.65 & 1.39 & 1.40 & 1.25 & 1.07 & Table 6. \\
Required return on equity capital (\%) & 14.64 & 12.96 & 12.26 & 11.06 & 9.65 & Median values of \\
Relative residual income (ROE- $r$ ) $(\%)$ & -6.02 & -3.54 & -1.64 & -0.94 & 0.22 & 8.64 estimated parameters \\
Risk-adjusted ROE (ROE-a) (\%) & 6.15 & 7.91 & 8.98 & 8.69 & 9.64 & \\
\hline
\end{tabular}

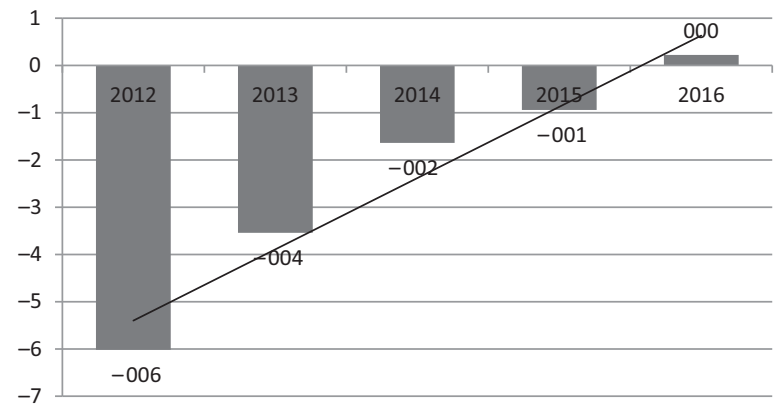

Figure 1.

Median relative residual income (ROE-r) (\%) for the analyzed companies in the period 2012-2016 
$\mathrm{K}$

51,2

670

relate instrumental aspects of core business processes to company risk-adjusted performance, further on we have based these on calculated ROE- $r$ and ROE-a and relate them to the instrumental aspects of core business processes (Table 7).

Due to the small sample and our decision to exclude $5 \%$ of companies with extreme five-years average performance measures (both tails), we then explored the differences in each instrumental aspect of core business process control activities assessments between the best performers $10 \%$ ( $\mathrm{N}=15$ companies) and the worst performers $10 \%(\mathrm{~N}=15$ companies) based on five-years average company risk-adjusted performance measures ROE- $r$ and ROE-a.

We checked for statistical differences in each instrumental aspect of the core business process control activities assessments between the best $10 \%$ and the worst $10 \%$ companies based on company risk-adjusted performance measures. We used a non-parametric MannWhitney $\mathrm{U}$ test. The results were not sufficiently significant to statistically prove the difference. Thus, we cannot statistically accept the developed hypothesis:

The instrumental aspect of control as a core process management activity has a statistically significant impact on the company risk-adjusted performance measures ROE-r and ROE-a.

The statistically insignificant differences could be expected due to the small sample size, notwithstanding the fact that there are significant differences between the assessments in all statements (see the assessments in Table 7). Nevertheless, we can see an interesting pattern in Table 7 that we did not expect. All statements: "the success of changes to the core processes is measured with the assistance of clearly defined indicators." "The success of changes to the core processes is measured by financial effects." "We do not deviate from the set goals of changes to the core processes in our company." and the statement "When measuring the success of changes to the core processes, we put short-term (immediate) benefits for the company in the foreground." show higher value for companies with lower ROE-a and ROE- $r$ that are, financially speaking, less successful.

In accordance with our theory, we expect a positive connection between BPM and company financial performance. However, even a negative connection could be explained. Business processes changes (process optimization, implementation of new technology, etc.) in less successful companies are subjected to much more scrutiny. Because of the restricted financial position of such companies, they must be more careful in making decisions. Less successful companies have limited access to financial resources so they must be more oriented on quick wins, which pushes them to put the financial effects of decision making on

Table 7.

Comparison of instrumental aspects of core business process control activities to ROE- $r$ and ROE-a

\begin{abstract}
oriented on quick wins, which pushes them to put the financial effects of decision making on
\end{abstract}

\begin{tabular}{|c|c|c|c|c|}
\hline \multirow{6}{*}{$\begin{array}{l}\text { Five-year average (\%) } \\
\text { The success of changes to the core processes is measured } \\
\text { with the assistance of clearly defined indicators } \\
\text { The success of changes to the core processes is measured } \\
\text { by financial effects } \\
\text { We do not deviate from the set goals of changes to the core } \\
\text { processes in our company } \\
\text { When measuring the success of changes to the core } \\
\text { processes, we put short-term (immediate) benefits for the } \\
\text { company in the foreground }\end{array}$} & \multicolumn{2}{|c|}{$\begin{array}{l}\text { ROE- } r \\
\text { best } 10 \% \text { worst } 10 \% \\
\text { companies companies }\end{array}$} & \multicolumn{2}{|c|}{$\begin{array}{l}\text { ROE-a } \\
\text { best } 10 \% \quad \text { worst } 10 \% \\
\text { companies companies }\end{array}$} \\
\hline & $17.66 \%$ & $-19.33 \%$ & $23.81 \%$ & $0.30 \%$ \\
\hline & 3.80 & 3.93 & 3.67 & 4.31 \\
\hline & 4.27 & 4.53 & 4.07 & 4.38 \\
\hline & 3.47 & 3.67 & 3.47 & 3.63 \\
\hline & 2.73 & 3.40 & 2.93 & 3.31 \\
\hline
\end{tabular}


process change in the front line. Of course, stronger evidence needs to be obtained before such a claim can be positively established.

On the other hand, based on the literature review we can conclude that successful companies have a better balance between the instrumental and interest aspects of process management. So, lower values of the instrumental aspect of the core business process are expected from this perspective.

\section{Conclusions}

This paper research studies the control of core business processes from the instrumental perspective and its effect on the industry-specific financial risk measures of company performance. For this purpose, we developed and tested a measurement instrument for measuring the instrumental aspects of BPM. For the performance measurement of companies, we used the risk-adjusted performance measures ROE- $r$ and ROE-a, which allow a joint analysis on a sample of companies from different industries.

We tested for statistical differences in each instrumental aspect of the core business process control activities assessments between best and worst companies based on company risk-adjusted performance measures. The results were not sufficiently significant to statistically prove the difference and to accept the hypothesis that the instrumental aspect of control as a core process management activity has a statistically significant impact on the company risk-adjusted performance measures ROE- $r$ and ROE-a.

Despite not being statistically proven (presumably due to the small sample size), the results suggest that the instrumental aspects of core business process control activities are negatively correlated to the risk-adjusted company performance measures ROE- $r$ and ROEa. This suggests that companies with lower ROE- $r$ and ROE-a are more focused on the instrumental aspects of BPM.

In accordance with our theory, we expected a positive connection between BPM and company financial performance. However, we tried to explain a negative connection with the following reasoning. Business processes changes in less successful companies are subjected to much more scrutiny. Because of the restricted financial position of such companies they must be more careful in making decisions as they must be more oriented on quick wins, which push them to put the financial effects of decision making on process change as the main goal. However, stronger evidence needs to be obtained before such a claim can be positively established.

Research implications of the results might concern investors, managers and BPM practitioners on the field of BPM improvements, especially in SMEs. A lack of BPM improvement measurement related to company performance can be the main obstacle of starting BPM improvement initiatives. On the other hand, understanding relations between core business processes and company performance and thus related risk-adjusted measures can direct managers to invest more in BPM at this time and to set priority management actions in the SMEs.

The main limitation of our purposed study model is that we have studied only control activities of core business processes and relate it to company risk-adjusted performance measures. The study has been limited also by the number of SMEs and thus related number of respondents and by the use of a survey as a research instrument. Results of this research could be affected by the possible subjective assessment of respondents (general managers, leaders, process owners) about BPM status in companies. An additional limitation of our research is the degree of reliability implied by the assumptions of the models used to estimate the required ROE and risk, and a certain degree of subjectivity in estimating the variables entering the models. However, we believe that the results are more relevant than they would be using performance measures without risk adjustment. Results of this research in SMEs cannot be generalized for large companies. In large companies, we have to 
$\mathrm{K}$

51,2

\section{2}

deal with a greater division of work, different approaches to business processes, deeper organizational structures, stronger positions on the market (e.g. against suppliers, customers).

Further research for a deeper understanding of how core business processes in SMEs are managed and how company performance can be improved would require a larger sample and a more varied research methodology. Further research could be performed in several directions:

- periodical studies on the same population or the sample, with latest company performance data;

- studying relationship between factors which were not included now, such as: company size and industry, type of the processes, BPM status in the company, awareness about BPM, position of participants included in the research);

- the same study on large companies; and

- comparison studies (in time and with similar economies).

This calls for totally new research based on a new questionnaire data collection regarding business processes.

\section{Notes}

1. For example, in the following finance literature: (Arnold, 2013; Brealey et al., 2012; Brigham and Ehrhardt, 2017; Damodaran, 2016).

2. Refer to Feltham and Ohlson (1996), Dechow et al. (1999), Biddle et al. (2001), Halsey (2001), Lundholm and O'Keefe (2001), Cheng (2005), Jamin (2005), Balachandran and Mohanram (2012).

3. Blitz et al. (2014) have combined the CAPM assumptions into the following groups: there are no constraints (e.g. on leverage and short-selling); investors are risk averse, maximise the expected utility of absolute wealth and care only about the mean and variance of return; there is only one period; information is complete and rationally processed; and markets are perfect (i.e. all assets are perfectly divisible and perfectly liquid, there are no transaction costs, there are no taxes, and all investors are price takers).

4. See Brigham and Ehrhardt (2011), Wright et al. (2003).

5. The Slovenian capital market is not efficient. Total market capitalisation of Ljubljana Stock Exchange (Ljubljana Stock Exchange, 2017) at the end of the year 2017 was $€ 5.3 \mathrm{bn}$, the annual turnover around $€ 350 \mathrm{~m}$. The market is small, with only nine actively traded stocks in the first quotation, and twenty stocks traded in the standard quotation.

6. Data from Fred (2020).

7. The European Central Bank (2020) aims at inflation rates of below, but close to $2 \%$ over the medium term.

8. We retrieved the data for all variables that we estimated from Damodaran (2020) except for the Slovenia net of United States credit default swap.

9. Most analysts use a market risk premium in the range of $4 \%$ to $7 \%$ (Brigham and Ehrhardt, 2017)

10. Data from Bloomberg (2020).

11. For more details, see Kruschwitz et al. (2012).

12. Damodaran (2020) betas are estimated by regressing weekly returns on stock against the local index using five years of data. Then a composite of the two-year regression beta and the five-year regression beta is used, weighting the former $2 / 3^{\text {rd }}$ and the latter $1 / 3^{\text {rd }}$. 


\section{References}

APQC (1992), "Process classification framework", available at: www.apqc.org (accessed 10 January 2021). Arnold, G. (2013), Corporate Financial Management, Pearson Education Limited, New York, NY.

Balachandran, S. and Mohanram, P. (2012), "Using residual income to refine the relationship between earnings growth and stock returns", Review of Accounting Studies, Vol. 17 No. 1, pp. 134-165.

Berends, H., Smits, A., Reymen, I. and Podoynitsyna, K. (2016), "Learning while (re)configuring: business model innovation processes in established firms”, Strategic Organization, Vol. 14 No. 3 , pp. 181-219.

Biddle, G.C., Chen, P. and Zhang, G. (2001), "When capital follows profitability: non-linear residual income dynamics”, Review of Accounting Studies, Vol. 6 Nos 2/3, pp. 229-265.

Blitz, D., Falkenstein, E. and Van Vliet, P. (2014), "Explanations for the volatility effect: an overview based on the CAPM assumptions", The Joumal of Portfolio Management, Vol. 40 No. 3, pp. 61-76.

Bloomberg (2020), "Financial data", available at: www.bloomberg.com/europe (accessed 10 October 2020).

Brealey, R.A., Myers, S.C., Allen, F. and Mohanty, P. (2012), Principles of Corporate Finance, McGrawHill Education, New York, NY.

Brigham, E.F. and Ehrhardt, M.C. (2011), Financial Management: Theory and Practice, Cengage Learning, Mason, $\mathrm{OH}$.

Brigham, E.F. and Ehrhardt, M.C. (2017), Financial Management: Theory and Practice, Cengage Learning, Mason, $\mathrm{OH}$.

Burlton, R.T. (2010). "Delivering business strategy through process management", Handbook on Business Process Management 2, Heidelberg, Springer.

Cheng, Q. (2005), “What determines residual income?”, The Accounting Review, Vol. 80 No. 1, pp. 85-112.

Christensen, P.O., Feltham, G.A. and Wu, M.G. (2002), "Cost of capital in residual income for performance evaluation", The Accounting Review, Vol. 77 No. 1, pp. 1-23.

Damodaran, A. (2016), Damodaran on Valuation: security Analysis for Investment and Corporate Finance, John Wiley and Sons, Hoboken, NJ.

Damodaran, A. (2020), "Damodaran online", available at: http://pages.stern.nyu.edu/ adamodar/ (accessed 10 October 2020).

De Wall, A. (2008), "The secret of high performance organizations", Management Online Review, Vol. 2008, pp. 1-10.

De Wit, B. and Meyers, R. (2005), Strategy Synthesis, Thomson Learning, London.

Dechow, P.M., Hutton, A.P. and Sloan, R.G. (1999), "An empirical assessment of the residual income valuation model”, Journal of Accounting and Economics, Vol. 26 Nos 1/3, pp. 1-34.

Easterby-Smith, M., Thorpe, R. and Lowe, A. (2007), "Raziskovanje v managementu”, Fakulteta za Management, Koper.

Espino-Rodriguez, F.T. and Rodríguez-Diaz, M. (2014), "Determining the core activities in the order fulfillment process: an empirical application”, Business Process Management Journal, Vol. 20 No. 1, pp. 2-24.

European Central Bank (2020), "Monetary policy", available at: www.ecb.int/mopo/html/index.en.html (accessed 10 October 2020).

Fama, E.F. and French, K.R. (1992), "The cross-section of expected stock returns", The Journal of Finance, Vol. 47 No. 2, pp. 427-465.

Feltham, G.A. and Ohlson, J.A. (1996), "Uncertainty resolution and the theory of depreciation measurement", Journal of Accounting Research, Vol. 34 No. 2, pp. 209-234.

Fernandez, P. (2015), “CAPM: an absurd model”, Business Valuation Review, Vol. 34 No. 1, pp. 4-23.

Fred (2020), "Federal reserve bank of St. Louis. Economic data", available at: www.ecb.int $/ \mathrm{mopo} / \mathrm{html} /$ index.en.html (accessed 10 October 2020). 
$\mathrm{K}$

51,2

Glen, A. (2005), Handbook of Corporate Finance, Prentice Hall, England, Harlow.

Gošnik, D. (2019a), "Core business process management and company performance”, Management, Vol. 14 No. 1, pp. 59-86.

Gošnik, D. (2019b), Management Temelinih Procesov: Instrumentalni in Interesni Vpliv na Uspešnost Podjetij, University of Primorska, Koper.

Gošnik, D., Beker, I., Suklan, J. and Kavčič, K. (2016), "Management model for successful business processes: the case of transition countries", International Journal of Industrial Engineering and Management, Vol. 7 No. 2, pp. 75-83.

Gvin (2020), "Financial data”, available at www.bisnode.si/produkti/bisnode-gvin/ (accessed 21 October 2020).

Halsey, R.F. (2001), "Using the residual-income stock price valuation model to teach and learn ratio analysis", Issues in Accounting Education, Vol. 16 No. 2, pp. 257-272.

Inkpen, A. and Choudhury, N. (1995), "The seeking of strategy where is not: towards the theory od strategic absence", Strategic Management Journal, Vol. 16 No. 4, pp. 313-323.

Jamin, G. (2005), Investment Performance of Residual Income Valuation Models on the German Stock Market, Research Papers of the Institute for Business Management.

Janeš, A., Biloslavo, R. and Faganel, A. (2017), "Sustainable business model: case study of Fonda", Annales - Series Historia et Sociologia, Vol. 27 No. 1, pp. 175-190.

Janeš, A., Kadoić, N. and Begičević Ređep, N. (2018), "Differences in prioritization of the BSC's strategic goals using AHP and ANP methods”, Journal of Information and Organizational Sciences, Vol. 42 No. 2, pp. 193-217.

Kruschwitz, L., Löffler, A. and Mandl, G. (2012), "Damodaran's country risk premium: a serious critique", Business Valuation Review, Vol. 31 Nos 2/3, pp. 75-84.

Lintner, J. (1965a), "Security prices, risk, and maximal gains from diversification", The Journal of Finance, Vol. 20 No. 4, pp. 587-615.

Lintner, J. (1965b), "The valuation of risk assets and the selection of risky investments in stock portfolios and capital budgets”, The Review of Economics and Statistics, Vol. 47 No. 1, pp. 13-37.

Ljubljana Stock Exchange (2017), “Annual reports”, available at: www.ljse.si/cgi-bin/jve.cgi?doc=676 (accessed 10 October 2020).

Lundholm, R. and O'Keefe, T. (2001), "Reconciling value estimates from the discounted cash flow model and the residual income model", Contemporary Accounting Research, Vol. 18 No. 2, pp. 311-335.

McGoun, E.G. (1993), “The CAPM: a Nobel failure”, Critical Perspectives on Accounting, Vol. 4 No. 2, pp. $155-177$.

Minonne, C. and Turner, G. (2012), "Business process management: are you ready for the future?", Knowledge and Process Management, Vol. 19 No. 3, pp. 111-120.

Mossin, J. (1966), "Equilibrium in a capital asset market”, Econometrica, Vol. 34 No. 4, pp. 768-783.

Nandakumar, M.K., Ghobadian, A. and O'Regan, N. (2009), “Generic strategies and performance - evidence from manufacturing firms", International Joumal of Productivity, Vol. 60 No. 3, pp. 222-251.

Niehaves, B., Poeppelbuss, J., Plattfaut, R. and Becker, J. (2014), "BPM capability development-a matter of contingencies”, Business Process Management Journal, Vol. 20 No. 1, pp. 90-106.

Novak, R. and Janeš, A. (2019), "Business process orientation in the Slovenian power supply", Business Process Management Journal, Vol. 25 No. 4, pp. 780-798.

Phanny, I. (2009), "Guideline for interpreting correlation coefficient”, available at: www.slideshare.net/ phannithrupp/guideline-for-interpreting-correlation-Coefficient (accessed 5 October 2020).

Potočan, V. and Mulej, M. (2009), "How to improve innovativeness of small and medium enterprises", Journal of Contemporary Management Issues, Vol. 14 No. 1, pp. 1-20.

Seethamraju, R. (2012), "Business process management: a missing link in business education”, Business Process Management Journal, Vol. 18 No. 3, pp. 532-547. 
Sharpe, W.F. (1964), "Capital asset prices: a theory of market equilibrium under conditions of risk", The Journal of Finance, Vol. 19 No. 3, pp. 425-442.

Strecker, N. (2009), Innovation Strategy and Firm Performance, GWV Fachverlage GmbH, Wiesbaden.

Stalk, G., Evans, P. and Shulman, L.E. (1992), "Competing on capabilities: the new rules of corporate strategy”, Harward Business Review, Vol. 70 No. 2, pp. 57-69.

Stojanović, D., Tomašević, I., Slović, D., Gošnik, D., Suklan, J. and Kavčič, K. (2017), "B.P.M. in transition economies: joint empirical experience of Slovenia and Serbia", Economic ResearchEkonomska Istraživanja, Vol. 30 No. 1, pp. 1237-1256.

Tavčar, M.I. (2009), "Management in organizacija”, Sinteza Konceptov Organizacije Kot Instrumenta in Kot Skupnosti Interesov, Fakulteta za management, Koper.

Treynor, J.L. (1961), Market Value, Time, and Risk, Unpublished manuscript.

Treynor, J.L. (1962), Toward a Theory of Market Value of Risky Assets, Unpublished manuscript.

Trkman, P. (2010), “The critical success factors of business process management”, International Journal of Information Management, Vol. 30 No. 2, pp. 125-134.

Trkman, P., Mertens, W., Viaene, S. and Gemmel, P. (2015), "From business process management to customer process management", Business Process Management Journal, Vol. 21 No. 2, pp. 250-266.

Thennakoon, D., Bandara, W., French, F. and Mathiesen, P. (2018), "What do we know about business process management training? Current status of related research and a way forward", Business Process Management Journal, Vol. 24 No. 2, pp. 478-500.

Vom Brocke, J., Schmiedel, T., Recker, J., Trkman, P., Mertens, W. and Viaene, S. (2014), “Ten principles of good business process management".

Wright, S. Mason, R. and Miles, D. (2003), "A study into certain aspects of the cost of capital for regulated utilities in the UK", available at: http://regulationbodyofknowledge.org/wp-content/ uploads/2013/03/Wright_-A_Study_into.pdf (accessed 5 October 2020).

Yong, A.G. and Pearce, S. (2013), "A beginners guide to factor analysis: focusing on exploratory factor analysis", Tutorials in Quantitative Methods for Psychology, Vol. 9 No. 2, pp. 79-94.

Zelt, S., Schmiedel, T. and Vom Brocke, J. (2018), "Understanding the nature of processes: an informationprocessing perspective", Business Process Management Journal, Vol. 24 No. 1, pp. 67-88.

\section{Further reading}

Kohlbacher, M. (2010), "The effects of process orientation: a literature review", Business Process Management Journal, Vol. 16 No. 1, pp. 135-152.

Lau, H., Dilupa, N., Premeratne, S. and Shum, P.K. (2016), "BPM for supporting customer relationship and profit decision”, Business Process Management Journal, Vol. 22 No. 1, pp. 231-255.

Macedo de Morais, R., Samir, K., Dallavalle de Paadua, S.I. and Costa Lucirton, A. (2014), "An analysis of BPM lifecycles: from a literature review to a framework proposal", Business Process Management Journal, Vol. 20 No. 3, pp. 412-432.

Ohlson, J.A. (2005), “On accounting-based valuation formulae”, Review of Accounting Studies, Vol. 10 Nos 2/3, pp. 323-347.

\section{Corresponding author}

Dušan Gošnik can be contacted at: dusan.gosnik@fm-kp.si

For instructions on how to order reprints of this article, please visit our website:

www.emeraldgrouppublishing.com/licensing/reprints.htm

Or contact us for further details: permissions@emeraldinsight.com 